ACTA MYCOLOGICA

Vol. 42 (1): 85-92

2007

\title{
Rare and interesting species of Psathyrella found in the Tatra National Park
}

\author{
ANNA RONIKIER \\ Department of Mycology, W. Szafer Institute of Botany, Polish Academy of Sciences \\ Lubicz 46, PL-31-512 Kraków, a.ronikier@ib-pan.krakow.pl
}

Ronikier A.: Rare and interesting species of Psathyrella found in the Tatra National Park. Acta Mycol. 42 (1): 85-92, 2007.

Three species of the genus Psathyrella are described and illustrated in the paper. One of them: P. hydrophiloides is new to Poland, while two others: P. conopilus and P. murcida are new to the Polish Carpathians.

Key words: Agaricales, Psathyrella conopilus, Psathyrella hydrophiloides, Psathyrella murcida, the Tatra Mts, Poland

\section{INTRODUCTION}

The genus Psathyrella (Fr.) Quél. is represented in Poland by 52 species, among which only three, namely: P. candolleana (Fr.: Fr.) Maire, P. piluliformis (Bull.: Fr.) P.D.Orton and P. prona (Fr.) Gillet, are common in Poland. Remaining species are known from few localities in the country, some of them are considered as threatened (Wojewoda 2003). Relatively low number of taxa reported from Poland to date and their rarity result probably from the difficulties in identification of species, their variability and long-lasting lack of sufficient monographs and keys. Only in late 70. and 80. of the last century the excellent work of Kits van Waveren $(1982,1985)$ brought a number of papers ordering and clarifying the taxonomical complexity within the genus Psathyrella. A great number of species newly described by him, re-description of others and many additional comments on morphological variability and ecological preferences, provided in his papers, improved the knowledge of the genus and facilitated identification of some less known taxa. For the last fifteen years several new to Poland species of the genus Psathyrella were reported (e.g. Wojewoda, Heinrich, Komorowska 1999). 


\section{MATERIALS AND METHODS}

In a framework of the study devoted to the diversity of agarics and boletes of the Sarnia Skała massif in the Tatra National Park (Ronikier 2005) a few interesting species of Psathyrella were found. The fungi were collected during the years 2000-2003 in a beech forest of lower montane belt (Dentario glandulosae-Fagetum) of a calcareous massif of Sarnia Skała. The descriptions of macro- and microcharacters provided below are based exclusively on the collected material. References to colours in descriptions of Psathyrella conopilus and P. murcida follow Kor n e r u p and Wanscher (1965). The spores were measured in 5\% $\mathrm{KOH}$. The spores for measurements were taken from a spore-print, from natural spore deposit present at stipe apex or only mature (the darkest) spores lying on a gill surface were measured. Drawings of microcharacters were made with the aid of drawing tube (Nikon Y-IDT). All measurements were done directly through the microscope (under oil immersion objective), not from the drawings. The distribution map provided for $P$. conopilus is based on literature data only and includes the new locality reported in this paper. Because usually there is no description of specimens which localities are mentioned in the source literature, the information could not be verified - no herbarium material was revised. The material is deposited at the Herbarium of the W. Szafer Institute of Botany, Polish Academy of Sciences, Kraków (KRAM) or the Herbarium of the T. Chałubiński Museum, Zakopane (ZAMU).

\section{DESCRIPTION OF SPECIES}

Psathyrella conopilus (Fr.: Fr.) A.Pearson et Dennis, 1948. Trans. Brit. Mycol. Soc. 31: 185.

syn. P. subatrata (Batsch) Gillet ss. M.M.Moser. (Figs 1, 3).

Description: Cap 20-30 mm in diameter, 15-25 mm high, broadly conical, hygrophanous, brown $(5 \mathrm{E} 4,5 \mathrm{E} 5,5 \mathrm{~F} 4,5 \mathrm{~F} 5)$, translucently striate, pallescent on drying to beige (4B3, 4B4), without red tints when dry, surface smooth. Veil absent. Lamellae distant, $3 \mathrm{~mm}$ broad, narrowly adnate, very dark brown to black, edge white ciliate. Stipe $70-130 \times 3 \mathrm{~mm}$, clavate, base swollen up to $0.5 \mathrm{~cm}$, cream (4A2), silky smooth, finely pruinose at apex. Context very thin, cream, smell and taste none.

Spores 15-17 $\times 8-9 \mu \mathrm{m}$ ellipsoid, smooth, thick-walled, with distinct central germ pore $2-2.5(3) \mu \mathrm{m}$ in diameter, grey-olive-brown in $5 \% \mathrm{KOH}$, warm brown in $10 \% \mathrm{NH}_{4} \mathrm{OH}$. Basidia $26-30 \times 11-12 \mu \mathrm{m}$, broadly clavate, with 4 sterigmata and basal clamp. Cheilocystidia 35-60 × 11-20 $\mu \mathrm{m}$, lageniform, utriform, ventricose, hyaline, thin-walled, numerous. Pleurocystidia none. Caulocystidia present at stipe apex, 37-72 × 10-20 $\mu \mathrm{m}$, cylindrical to lageniform with rounded and often slightly broadened apex. Pileipellis a hymeniderm, built up of clavate cells $27-45 \times 20-26$ $\mu \mathrm{m}$; red-brown, thick-walled setae 100-300 $\mu \mathrm{m}$ long present in pileipellis. Hymenophoral trama pale yellow-brown in $10 \% \mathrm{NH}_{4} \mathrm{OH}$. Clamps present.

Specimens eXAmined: S Poland, the Western Tatra Mts, the Sarnia Skała massif, mouth of the Dolina Strążyska valley, orographically right side of the valley, N slopes of the Grześkówki ridge, alt. 950 m a.s.l., Dentario glandulosae-Fagetum, on soil, N 49¹6'43” E 1956'27”, 14.10.2003, leg. A. Ronikier, KRAM F-54148. 
Notes: Psathyrella conopilus is a very remarkable fungus easy to distinguish from other species. It is characterized macroscopically by brown conical cap without red tinges, long stipe, slightly swollen at base and absence of veil. The most distinctive microscopical character is the presence of thick-walled setae in pileipellis. The species belongs to the section Subatratae (Romagn.) ex Singer and it is the only European member of this section. For the synonymy of the species see Kits van Waveren (1985) and Enderle (1992).
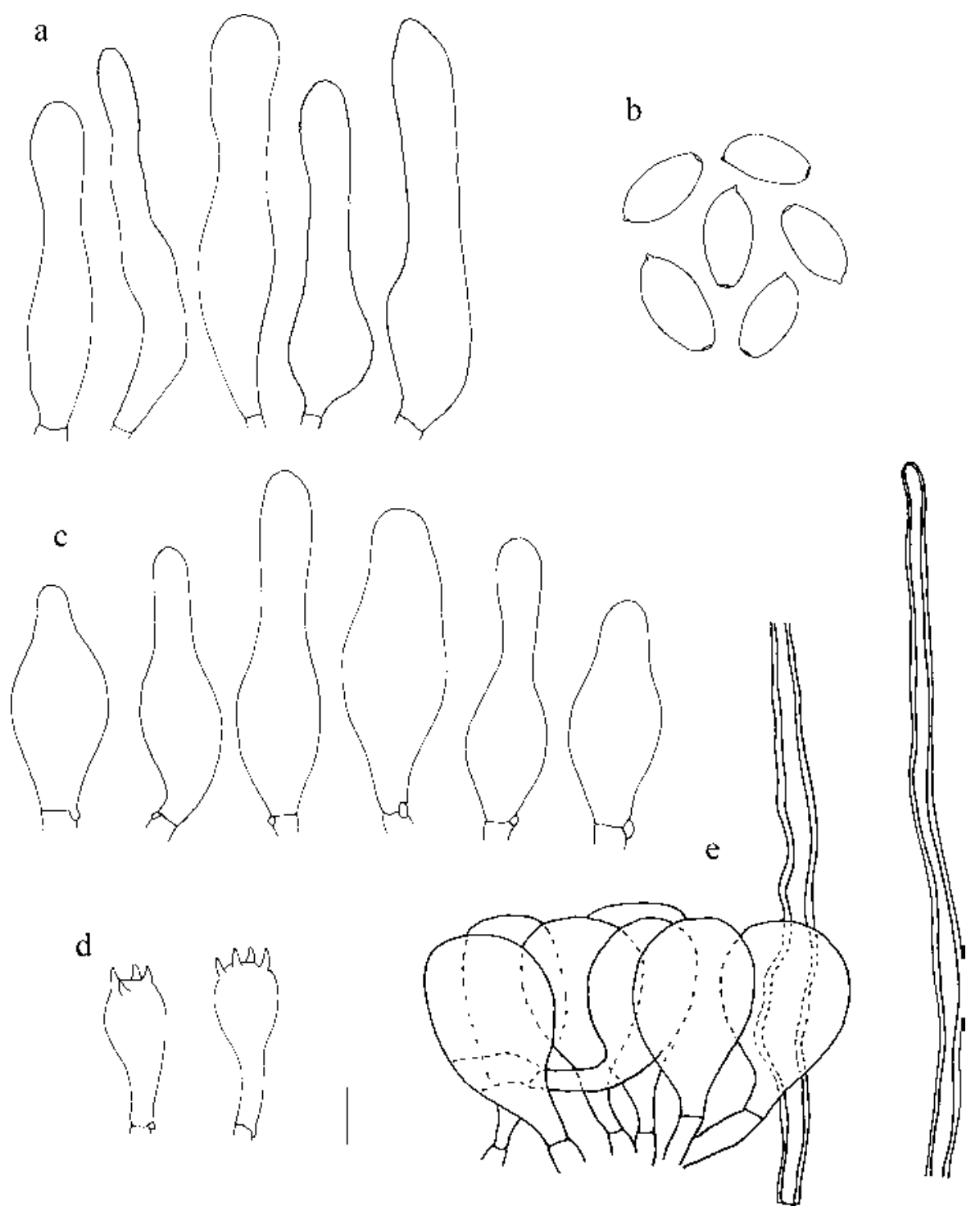

Fig. 1. Psathyrella conopilus (Fr.: Fr.) A. Pearson et Dennis, coll. KRAM F-54148; $\mathrm{a}-$ caulocystidia, $\mathrm{b}$ - spores, $\mathrm{c}-$ cheilocystidia, $\mathrm{d}$ - basidia, $\mathrm{e}-$ pileipellis; scale bar $=10 \mu \mathrm{m}$. 


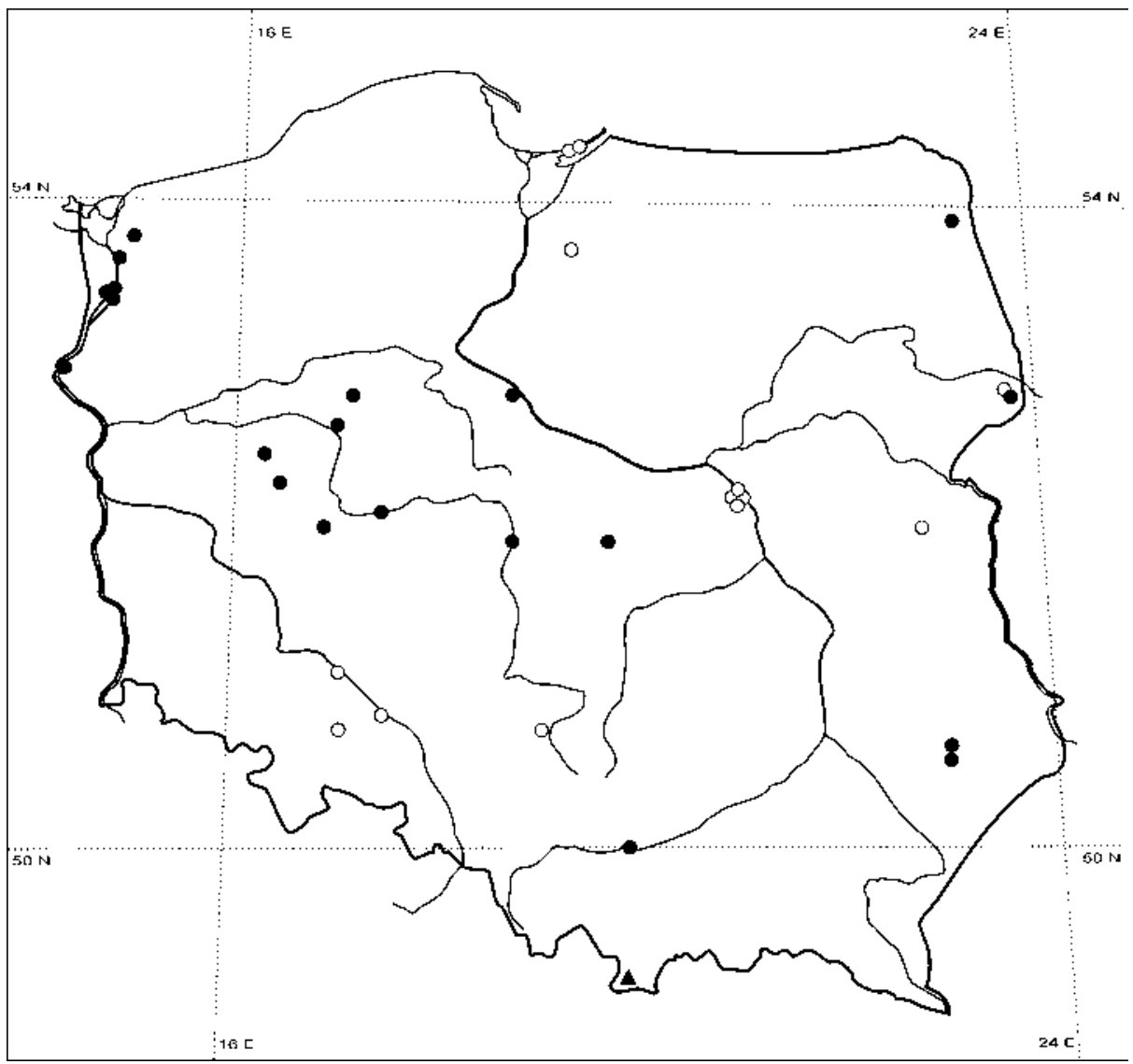

Fig. 2. Distribution of Psathyrella conopilus in Poland; white circle - localities reported before 1945 (some of them may be doubtful), black circle - after 1945, black triangle - new locality.

Distribution in Poland: The species was reported from several localities in Poland (Fig. 2). The interpretation of the species in older literature is not clear. In most source data only the name of species is given, without any description of specimens. Sometimes the description is provided, but it is too short or it disagrees with the modern interpretation of the species (e.g. spores are smaller). Without revision of herbarium specimens it is not possible to verify such data. For this reasons older records (before 1945) are marked with empty circle in the map.

The locality from the Tatra Mts is the first one in the Polish Carpathians.

Psathyrella hydrophiloides Kits van Wav., 1982. Persoonia 11 (4): 488. (Figs 4a, 5).

DESCRIPTION: Cap 20-25 mm in diameter, $15 \mathrm{~mm}$ high, broadly conical, hygrophanous, chocolate-brown, not translucently striate, pallescent on drying to ochraceousbeige without red tints, surface densely radially wrinkled. Veil not seen. Lamellae distant, $2 \mathrm{~mm}$ broad, very narrowly adnate, dark brown, edge finely white ciliate. Stipe $15 \times 4 \mathrm{~mm}$, whitish, very finely fibrilose, silky, with dense woolly mycelium forming volva-like structure at base, hollow. Context thin, wood colour, smell and taste none. Spore-print dark brown. 


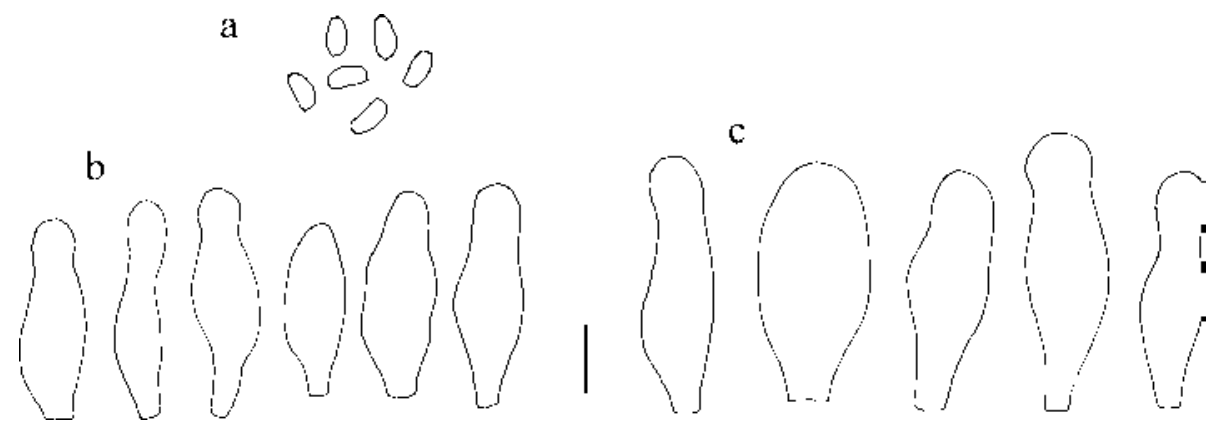

Fig. 5. Psathyrella hydrophiloides Kits van Wav., coll. KRAM F-54446; $\mathrm{a}-$ spores, $\mathrm{b}$ - cheilocystidia, $\mathrm{c}-$ pleurocystidia; scale bar $=10 \mu \mathrm{m}$.

Spores 5.5-6 $\times 3-3.5 \mu \mathrm{m}$ ellipsoid in face view, slightly phaseoliform in profile view, smooth, thick-walled, with a distinct germ pore $1-1.5 \mu \mathrm{m}$ in diameter, greyishbrown in $\mathrm{KOH}$, pale brown in $10 \% \mathrm{NH}_{4} \mathrm{OH}$. Basidia difficult to observe, insufficient to make measurements and drawings. Cheilocystidia 18-25 $\times 5-10 \mu \mathrm{m}$, utriform, some of them swollen at apex, hyaline, thin-walled, numerous. Pleurocystidia similar, 30-35 $\times 8.5-16 \mu \mathrm{m}$. Hymenophoral trama yellowish-brown in $10 \% \mathrm{NH}_{4} \mathrm{OH}$. Clamps numerous in cortical layer of the stipe.

SPeCimens EXAmined: S Poland, the Western Tatra Mts, the Sarnia Skała massif, lower part of the Dolina Spadowiec valley, alt. $950 \mathrm{~m}$ a.s.l., Dentario glandulosaeFagetum, on wood, under side of a fallen trunk of Fagus sylvatica covered by rhizomorphs of Armillaria sp., N 49¹6’36” E 1957’7”, 01.12.2000, leg. A. Ronikier, KRAM F-54446.

Notes: P. hydrophiloides belongs to the section Hydrophilae Romagn. ex Singer emend. Kits van Wav., for which chief characters are, among others, small, relatively pale spores and pigmented hymenophoral trama (Kits van Waveren 1982). The species is very close to P. piluliformis (Bull.: Fr.) P.D.Orton (=P. hydrophila (Bull.) Maire apud Maire et Werner) from which it differs by a scanty veil, solitary occurrence and a distinct germ pore in spores. In the original description Kits van Wave re n (1982) mentions the terrestrial habitat of the species. On the other hand, he states that specimens of Drosophila appendiculata var. piluliformis ss. Ricken described by Küh ner and Rom a g ne si (1953) belongs to the same species. Although Kühner and Romagnesi (1953) did not mention the habitat of the variety, the fungus depicted in the fig. 494 is presented on a piece of wood (black element at the stipe base). The specimens from the Tatra Mts. were also collected on wood.

Distribution in Poland: The species is new to Poland.

Psathyrella murcida (Fr.) Kits van Wav., 1985, Persoonia Suppl. 2: 281. (Figs 4b, 6).

DESCRIPTION: Cap 20-40 mm in diameter, first hemispherical, then broadly conical, paraboloid, hygrophanous, grey-brown, chocolate-brown (5E6, 5F6, 5D5, 5E5), translucently striate, pallescent on drying to ochraceous, ochraceous-beige without red tints $(4 \mathrm{C} 4,4 \mathrm{C} 5)$, surface smooth. Veil present, white, fugacious, visible only in young specimens. Lamellae moderately distant, very broad $(6 \mathrm{~mm})$, broadly adnate, chocolate-brown (5D4, 5E4), edge white ciliate or almost even. Stipe 40-100 × 3-6 


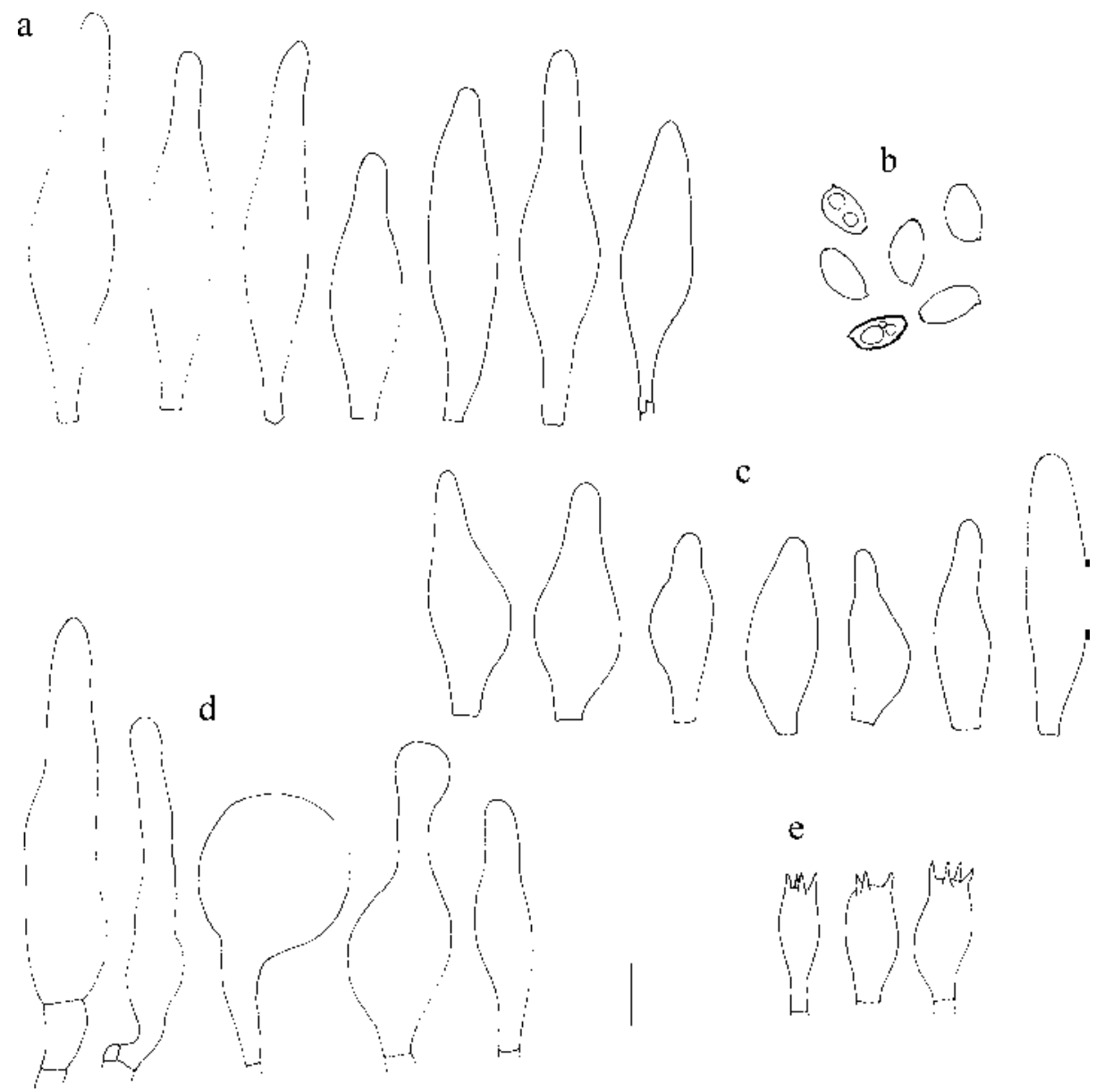

Fig. 6. Psathyrella murcida (Fr.) Kits van Wav., coll. KRAM F-50386;

$\mathrm{a}$ - pleurocystidia, $\mathrm{b}$ - spores, $\mathrm{c}$ - cheilocystidia, $\mathrm{d}$ - caulocystidia, $\mathrm{e}$ - basidia; scale bar $=10 \mu \mathrm{m}$.

$\mathrm{mm}$, cylindrical, sometimes slightly swollen at base, hollow, whitish-cream, dirty white, silky, apex finely pruinose. Context thin, beige in cap, whitish-beige in stipe, smell and taste none. Spore-print very dark brown, almost black.

Spores 9-11(12) $\times$ 5-6 $\mu \mathrm{m}$ ellipsoid, smooth, thick-walled, with small but distinct central germ pore about $1.5 \mu \mathrm{m}$ in diameter, grey-olive-brown in $\mathrm{KOH}$, sordid brown in $10 \% \mathrm{NH}_{4} \mathrm{OH}$. Basidia $18-21 \times 6.5-10 \mu \mathrm{m}$, broadly clavate, with 4 sterigmata. Cheilocystidia 28-46 $\times 9-15 \mu \mathrm{m}$, obtusely fusiform, lageniform, cylindrical, hyaline, thin-walled, numerous. Pleurocystidia 43-72 $\times 7-16 \mu \mathrm{m}$, narrowly obtusely fusiform, hyaline, abundant. Caulocystidia present at stipe apex, 43-62 $\times 9-30 \mu \mathrm{m}$, cylindrical, lageniform, narrowly fusiform or sphaeropedunculate. Hymenophoral trama pale beige. Clamps present. Veil composed of hyphae.

Specimens eXamined: S Poland, the Western Tatra Mts, the Sarnia Skała massif: upper part of the Dolina Spadowiec valley, orographically right side of the valley, alt. 1090 m a.s.l., Dentario glandulosae-Fagetum, on litter (leaves of Fagus sylvatica), 
N 49¹6'24”' E 1957'7’, 8.11.2000, leg. A. Ronikier, KRAM F-50386; lower part of the Dolina Strążyska valley, orographically right side of the valley, alt. $960 \mathrm{~m}$ a.s.l., Dentario glandulosae-Fagetum, on litter (leaves of Fagus sylvatica), N 49¹6’36" E 1956'17', 24.11.2000, leg. A. Ronikier, KRAM F-50458; lower part of the Dolina Białego valley, at the Droga pod Reglami hiking trail, alt. $940 \mathrm{~m}$ a.s.l., Dentario glandulosae-Fagetum, on litter (leaves of Fagus sylvatica), N 49¹6'44" E 1957'23”, 14.10.2003, leg. A. Ronikier, KRAM F-54443; the same, 3.10.2002, leg. A. Ronikier, ZAMU 4407; the Dolina Spadowiec valley, western slope (right side of the valley), alt. 1020 m a.s.l., Dentario glandulosae-Fagetum, on litter (leaves of Fagus sylvatica), N 49¹6'26” E 1957'01', 3.10.2002, leg. A. Ronikier, KRAM F-54444; lower part of the Dolina Strążyska valley, the Grześkówki ridge, alt. $960 \mathrm{~m}$ a.s.l., Dentario glandulosae-Fagetum, on litter (on small piece of wood of ?Fagus sylvatica), N 49¹6'39' E 1956'26”, 3.10.2002, leg. A. Ronikier, KRAM F-54445.

Notes: Östradius (1992) pointed out that Psathyrella murcida in a modern sense is not in agreement with Fries' original description of Agaricus murcidus referring to a small, fragile species placed in vicinity of $A$. gracilis Fr. This author, however did not propose any nomenclatural solutions. The disagreement with a protologue had been already noticed by Kühner and Romagnesi (1953) who followed Ricken's interpretation of the species. P. murcida is considered by modern authors (e.g. Kits van Waveren 1985; Vesterholt, Knudsen 1992; Horak 2005) as a relatively large sized species with fugacious veil, obtusely-fusiform cystidia and large spores, occurring in Fagus forests.

P. murcida is the most similar to $P$. fusca (Schumach.) A. Pearson from which it differs, among others, in the shape and size of pleurocystida. It occurs also later in season than the latter species. $P$. murcida is a late-autumn fungus, fairly common in Fagus forests of the investigated area where it was collected since beginning of October till end of November.

Distribution in Poland: Psathyrella murcida was reported from a few localities in Poland. Some records, however, seem to be doubtful. As it is believed to be a beech wood species (Kits van Waveren 1985; Kühner, Romagnesi 1953; Vesterholt,Knudsen 1992) occurring late in the season, records from forests without admixture of Fagus sylvatica: Galio-Carpinetum - date of collection not mentioned and Querco-Carpinetum - collected in 22 Aug. (Bujakiewicz, Fiklewicz 1963; Lisiewska, Połczyńska 1998) probably refer to other species of deciduous forests. Apart from the new locality given in this paper, the fungus was reported from beech forest and pine forest with admixture of Fagus sylvatica and Abies alba in Roztocze region, eastern Poland (D o mańs ki 1997, 1999).

Acknowledgments: My thanks are due to Professor Barbara Gumińska (Kraków) for permission to use her database and to Mr. Marian Wysocki and Mr. Jacek Wieser (Kraków) for kindly providing me with a background of a map of Poland elaborated by them. This work is a result of studies carried out within a grant no. 6 P04G 08320 financed by the Polish State Committee of Scientific Research (KBN). 


\section{REFERENCES}

Bujakiewicz A., Fiklewicz G. 1963. Grzyby wyższe lasów dębowo-grabowych okolic Opalenicy (pow. Nowy Tomyśl, Wielkopolska). Bad. Fizjogr. Pol. Zach., B 12: 277-300.

Domański Z. 1997. Przyczynek do znajomości flory mikologicznej Roztocza (msc).

Dom ański Z. 1999. Nowe stanowiska rzadkich i interesujących grzybów w Polsce (msc).

Ender le M. 1992. Studien in der Gattung Psathyrella II. Beiträge zur Kenntnis der Pilze Mitteleuropas 8: 85-102.

Hor a k E. 2005. Röhrlinge und Blätterpilze in Europa. Kryptogamenflora, Band IIb/2, 6. Aufläge. Spektrum Akad. Verlag, München.

Kits van Waveren E. 1982. Notes on the genus Psathyrella-VIII. Persoonia 11 (4): 473-508.

Kits van Waveren E. 1985. The Dutch, French and British species of Psathyrella. Persoonia 2 suppl.

Kornerup A., Wanscher J.H. 1965. Farver i Farver [Methuen Handbook of Colour]. Politikens Forlag, København.

Kühner R., Romagnesi H. 1953. Flore analytique des champignons supérieurs. Masson et $\mathrm{C}^{\mathrm{ic}}$ Éditeurs, Paris.

Lisiewska M., Połczyńska M. 1998. Changes in macromycetes of the oak-hornbeam forests in the "Dębina" reserve (Northern Wielkopolska). Acta Mycol. 33 (2): 191-230.

Östradius L. 1992. On the interpretation of Psathyrella murcida and P. fusca. Persoonia 14 (4): 543546.

Ronikier A. 2005. Bioróżnorodność grzybów agarykoidalnych i boletoidalnych Sarniej Skały w Tatrzańskim Parku Narodowym. W. Szafer Institute of Botany, Polish Academy of Sciences, Kraków (PhD thesis).

Vesterholt J., Knudsen H. 1992. Psathyrella (Fr.) Quél. (In:) L. Hansen, H. Knudsen (eds). Nordic Macromycetes 2. Nordsvamp, Copenhagen: 236-252.

Woje woda W. 2003. Checklist of Polish larger Basidiomycetes. (In:) Z. Mire k (ed.). Biodiversity of Poland 7. Institute of Botany, Polish Academy of Sciences, Kraków.

Wojewoda W., Heinrich Z., Komorowska H. 1999. Macromycetes of oak-lime-hornbeam woods in the Niepołomice Forest near Kraków (S Poland) - monitoring studies. Acta Mycol. 34 (2): 201-266.

\section{Rzadkie i interesujące gatunki z rodzaju Psathyrella znalezione w Tatrzańskim Parku Narodowym}

\section{Streszczenie}

W niniejszej pracy przedstawiono trzy interesujące gatunki z rodzaju Psathyrella. Jeden z nich, $P$. hydrophiloides, nie był dotychczas podawany z terenu Polski. Jest to rzadki grzyb również w Europie. Dwa kolejne gatunki zostały podane po raz pierwszy dla polskich Karpat. $P$. murcida jest rzadkim grzybem związanym z bukiem, natomiast $P$. conopilus występuje głównie w lasach liściastych. Ten ostatni gatunek znany jest w Polsce z około 30 stanowisk. Zamieszczono dokładne opisy cech makro- i mikroskopowych przedstawianych gatunków, jak również zdjęcia ich owocników oraz rysunki cech mikromorfologicznych. Dla P. conopilus opracowano mapę rozmieszczenia w Polsce na podstawie dotychczas opublikowanych danych. 


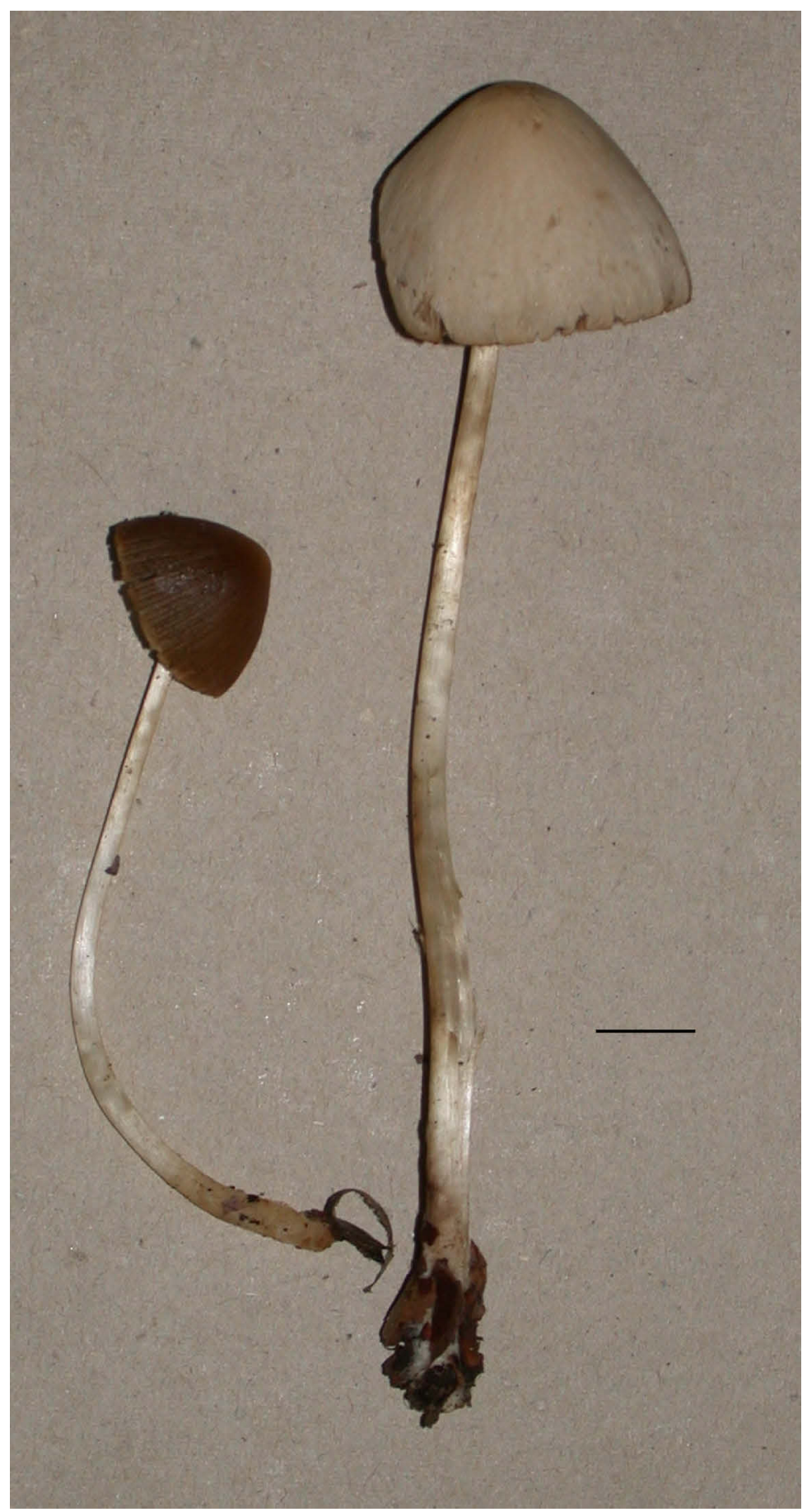

Fig. 3. Psathyrella conopilus (Fr.: Fr.) A. Pearson et Dennis, coll. KRAM F-54148; scale bar $=10 \mathrm{~mm}$. 

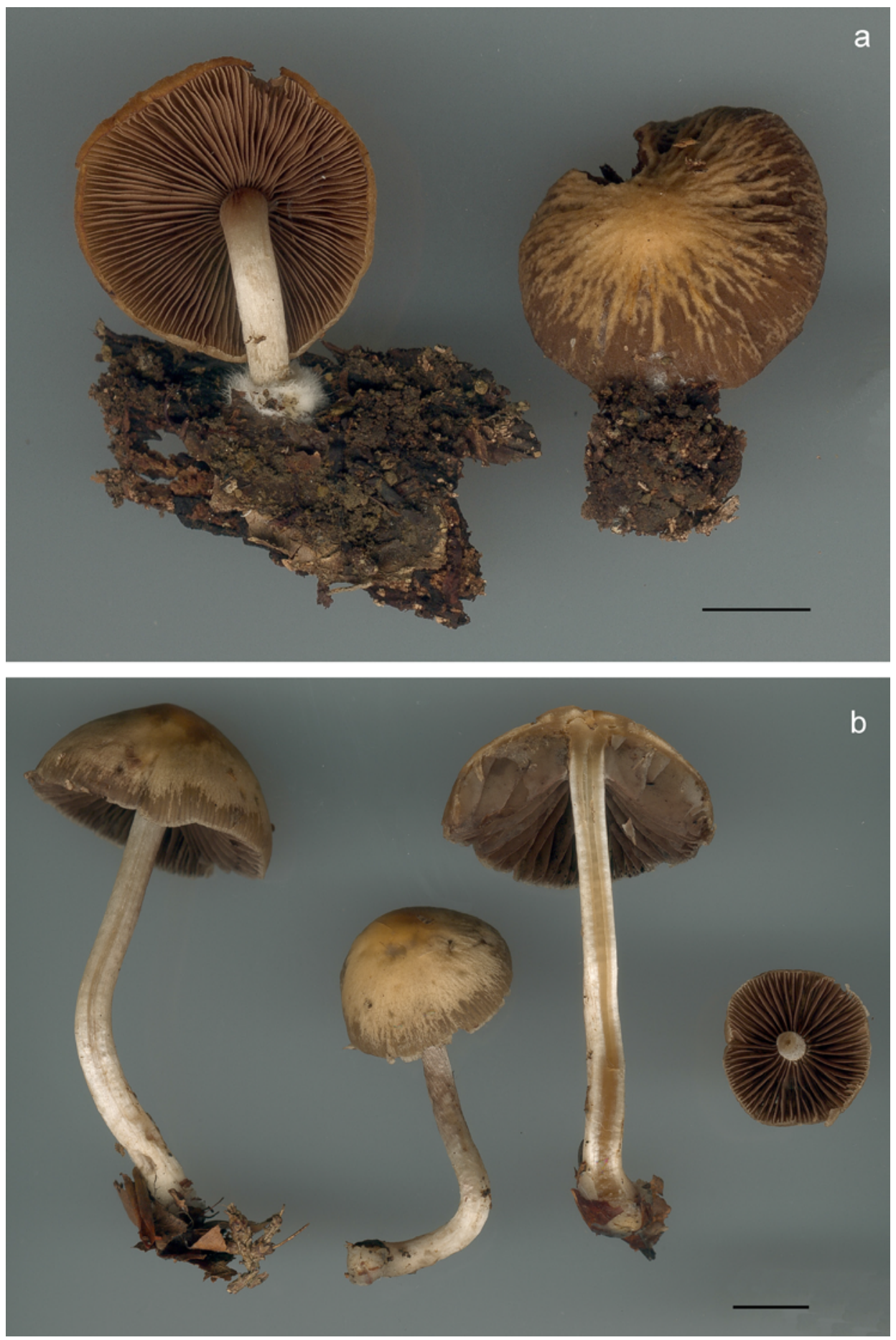

Fig. 4a - Psathyrella hydrophiloides Kits van Wav., coll. KRAM F-54446; b - Psathyrella murcida (Fr.) Kits van Wav., coll. KRAM F-50386; scale bar $=10 \mathrm{~mm}$. 